\title{
Case report on C-411/10, N.S. and C-493/10, M.E. and others,
}

\section{December 2011}

\section{Sophie Lieven}

Assistant, Institut d'Études Juridiques Européennes (IEJE), University of Liège, Belgium

LL.M. student, Katholieke Universiteit Leuven

Email address: $\underline{\text { Sophie.Lieven@ulg.ac.be }}$

\begin{abstract}
:
The European Court of Justice clarified through this judgment the way in which the overloading of a Member States' asylum system affects the EU arrangements for determining the Member State responsible for asylum applications lodged in the EU and thereby drastically reduced the possibility granted to Member States to transfer asylum applicants. The Member States now have an obligation to verify that no serious risk of violation of the Charter rights of the applicant exits in the receiving country before being allowed to transfer the person. The practical consequences of this ruling are still uncertain but further cooperation between Member States should be able to enhance the level of protection of human rights within the Common European Asylum System.
\end{abstract}

\section{Keywords:}

Asylum - Dublin Regulation - suspension of the transfer mechanism - Human Rights European Convention on Human Rights - Charter of Fundamental Rights of the European Union

\footnotetext{
${ }^{1}$ Case C-411/10, NS v Secretary of State for the Home Department, [2011], not yet published
} 


\section{Introduction}

On the $21^{\text {st }}$ December 2011, the European Court of Justice (ECJ) handed down a judgment that had been awaited for long by legal scholars and asylum law practitioners alike. The N.S. case concerned an afghan asylum seeker who sought asylum in the $\mathrm{UK}^{2}$. As he had entered the European Union through Greece, the United Kingdom could transfer him back to this country, Greece being the responsible Member State for the asylum application according to the Dublin Regulation. ${ }^{3}$ Mr N.S. appealed against the decision to transfer him to Greece, claiming that his human rights would be infringed by such a transfer. A couple of months earlier this year, the European Court of Human Rights (ECtHR) had already declared with its judgment in the case M.S.S v. UK ${ }^{4}$ that the transfer of an asylum applicant to Greece under the Dublin Regulation was contrary to the ECHR and had to be suspended. Indeed, the Greek asylum system was overloaded and a lot of deficiencies occurred ${ }^{5}$. Greece thus was found to breach Article 3 ECHR (which prohibits inhuman or degrading treatment). Even if the M.S.S. v. UK judgment had not been taken at the time the British Court of Appeal had to decide on N.S.'s transfer, the deficiencies and potential inhuman and degrading treatment of asylum seekers in Greece were already on the mind of the judges. ${ }^{6}$ The Court of Appeal thus decided to refer a question to the ECJ to know how it needed to interpret the Dublin Regulation under these circumstances. The crucial question was if the ECJ would follow the same line of reasoning as the ECtHR to interpret the compatibility of the Dublin transfer in light of the

\footnotetext{
${ }^{2}$ Case C-411/10 has been joined with case C-493/10 which concerned a similar situation and in substance asked the same questions. This is why this paper will only focus on the facts of the former one.

${ }^{3}$ Council Regulation (EC) No 343/2003 of 18 February 2003 establishing the criteria and mechanisms for determining the Member State responsible for examining an asylum application lodged in one of the Member States by a third country national, OJ L 50, 25.2.2003

${ }^{4}$ M.S.S. v. UK, Application no. 30696/09, 21 January 2011

5 UNHRC. Observations on Greece as a country of asylum. (December 2009). Available under http://www.unhcr.org/refworld/pdfid/4b4b3fc82.pdf

${ }^{6}$ Labayle, H., 2011. Le droit européen de l'asile devant ses juges: précisions ou remise en question ? Revue Francaise de Droit Administratif, pp. 286
} 
Charter $^{7}$, and which consequences it might draw on the system as such.

The N.S. judgment eventually clarifies the way in which the overloading of a Member States' asylum system affects the EU arrangements for determining the Member State responsible for asylum applications lodged in the EU. Indeed, the Grand Chamber of the ECJ concluded that a Member State cannot transfer an asylum seeker to another Member State, even if this is the outcome of an assessment under the Dublin Regulation, where there is a serious risk that its Charter rights will be violated. This suspension of the Dublin system is the key point of the judgment: Member States which, until now, fully respected their obligations under the Dublin Regulation, have to change their application of it in order to ensure that the asylum applicants' fundamental rights are respected.

In order to understand the case properly, it is necessary to first recall the main aims of the Dublin system, those being an important element in the ruling (2). The presumptions on which the national courts rely in the framework of this system will then be discussed (3). An analysis of the deficiencies of the system as well as the answer given by the ECtHR in the M.S.S. judgment will follow (4) before analysing the ECJ's reasoning in the NS case (5) and looking at the potential implications of this judgment (6). ${ }^{8}$

\footnotetext{
${ }^{7}$ Charter of fundamental rights of the European Union, OJ C 83, 30.3.2010, p. 1

${ }^{8}$ The details of the national procedures regarding asylum application won't be addressed, as a matter of place and relevance to the analysis of the judgment.
} 


\section{Aim of the Dublin System}

The Dublin Regulation ${ }^{9}$, which determines the Member State responsible for the examination of an asylum application ${ }^{10}$ pursues several goals: it aims at preventing multiple asylum applications as well as asylum shopping (i.e. the refugee chooses the most favourable Member State to apply for asylum) and avoiding the phenomenon of "refugees in orbit" (i.e. asylum seekers in search of a responsible Member State). It should furthermore make it possible to determine quickly the Member State responsible, to enhance the legal certainty of the applicant's situation. ${ }^{11}$ A fundamental characteristic of the system for allocating responsibilities in asylum cases is that, in principle, a single Member State is responsible for each asylum application lodged in the European Union. ${ }^{12}$ Where a third-country national has applied for asylum in a Member State which is not primarily responsible for examining that application, the regulation provides for mechanisms for the transfer of the asylum seeker to the Member State responsible. ${ }^{13}$ The consequence of this system is that every Member State is allowed to transfer the applicant to the Member State which is responsible following the criteria of the Regulation.

In the case at hand, the UK applied the Regulation to transfer Mr N.S. to Greece, being the Member State responsible in case of an illegal entry into the EU as it was the Member State of first entry. ${ }^{14}$ The Dublin Regulation contains, however, an important provision which

\footnotetext{
${ }^{9}$ Council Regulation (EC) No 343/2003

${ }^{10}$ When this application has been made by a third country national on the territory of one of the Member States of the European Union, Norway and Iceland.

${ }^{11}$ Opinion of Advocate General Trstenjak, Case C-411/10, NS v Secretary of State for the Home Department, paragraph 94 and paragraph 125

${ }^{12}$ For a deeper analysis see Moreno-Lax, V., 2012. Dismantling the Dublin System: M.S.S. v Belgium and Greece. European Journal of Migration and Law 1, p. 1

${ }^{13}$ Opinion of AG Trstenjak, paragraph 2

${ }^{14}$ It must be noted that this responsibility expires 12 months after the illegal entry.
} 
gives discretionary power to the Member States: the sovereignty clause. ${ }^{15}$ This clause allows a State to take it upon itself to process the asylum application even if another Member State is responsible following the criteria laid down by the Regulation. To that effect, the Regulation does not lay down any criteria so that the Member States are completely free ("sovereign") to decide to keep the application or to transfer the person to the responsible Member State. ${ }^{16}$

The Dublin system thus seems to be a comprehensive system on which the Member States can rely to transfer an asylum applicant to another Member State. Nonetheless, even if the Member States transferred powers on asylum policy to the European Union, the Vienna Convention on the Law of Treaties requires the Member States to comply with their obligations arising out of the relevant international treaties they ratified before the transfer of competence to the EU. ${ }^{17}$ The consequence of this is that Member States are still bound to comply with human rights obligations arising out of the several treaties they had ratified.

\section{The Compliance of the Dublin System with Human Rights Treaties ${ }^{18}$ : the Presumptions of Compliance and their Assessment by the European Court of Human Rights}

The Dublin system has harmonised several aspects of the national asylum systems in the EU. However, the final responsibility to grant international protection to those who

\footnotetext{
${ }^{15}$ This clause is contained in Article 3(2) of the Dublin Regulation

${ }^{16}$ For an analysis of the divergent use of the clause by the Member States see Moreno-Lax, V., op. cit., p. 16

${ }^{17}$ This is known as the Pacta sunt servanda principle (Article 26 of the Vienna Convention on the Law of Treaties)

${ }^{18}$ For an in-depth analysis of the relationship between EU asylum law and international law, please refer to Battjes, H. (2006). European Asylum Law and International Law. Martinus Nijhoff Publishers, Leiden, The Netherlands. In particular Chapters 2 and 9.
} 
deserve it still lays with the Member States themselves.

Even if the European Union as such is not a Contracting Party to the Geneva Convention, Article 78 TFEU and Article 18 of the Charter ${ }^{19}$ provide that the right to asylum should be guaranteed with due respect for this Convention. ${ }^{20}$. This Convention lays down, among others, the principle of non-refoulement ${ }^{21}$ which shall constitute a guarantee that no refugee will be sent back to a place where he will be persecuted. ${ }^{22}$

In applying their national asylum system, Member States must respect a triple layer of protection: not only the Geneva Convention and the ECHR, but also EU primary law (among which the Charter) and secondary law (among which the several directives and regulations forming the Dublin system).

On the basis that all Member States are bound by the same human rights obligations, most national courts relied on a double presumption ${ }^{23}$ :

- A first presumption that all Member States respect the principle of non-refoulement.

- A second presumption that all the Member States of the European Union can be considered as being safe countries. ${ }^{24}$

Those presumptions are part of the mutual trust which is expected between the

\footnotetext{
${ }^{19}$ Article 18 of the Charter: "The right to asylum shall be guaranteed with due respect for the rules of the Geneva Convention of 28 July 1951 and the Protocol of 31 January 1967 relating to the status of refugees and in accordance with the Treaty on European Union and the Treaty on the Functioning of the European Union (hereinafter referred to as "the Treaties')"

${ }^{20}$ The Tampere conclusions stated that the CEAS was to be based on the full and exclusive application of the Geneva Convention The Tampere conclusions also reaffirmed the necessary compliance with human rights obligations by saying that the European integration is firmly rooted in the "shared commitment to freedom based on human rights, democratic institutions and the rule of law" (paragraph 1 of the conclusions)

${ }^{21}$ Article 33 of the Geneva Convention states that "No Contracting State shall expel or return ( "refouler" ) a refugee in any manner whatsoever to the frontiers of territories where his life or freedom would be threatened on account of his race, religion, nationality, membership of a particular social group or political opinion".

${ }^{22}$ Furthermore, according to Article 21 of Directive 2004/83 $3^{22}$, Member States shall respect the principle of nonrefoulement in accordance with their international obligations

${ }^{23}$ Maiani, F. and Néraudau, E., 2011. L'arrêt M.S.S./ Grèce et Belgique de la Cour EDH du 21 janvier 2011. De la détermination de l'État responsable selon Dublin à la responsabilité des États membres en matière de protection des droits fondamentaux. Revue du droit des étrangers 162, p. 5

${ }^{24}$ Moreno-Lax, V., op. cit. p. 4
} 
Member States. Mutual trust in the quality and efficiency of each other's asylum systems is indeed a precondition to the fair and efficient operation of the Dublin system ${ }^{25}$ and has always been an essential element of the Common European Asylum System. ${ }^{26}$

As a consequence of those presumptions, a quasi automatic transfer by the migration authorities to the responsible Member State was frequently the case. It can be argued that those presumptions are justified from a theoretical point of view. However, a transfer under the Dublin system is an expulsion measure which falls under the scope of the prohibition of refoulement. Therefore, the authorities have to make sure that the asylum applicant they wish to transfer to another State will be safe there. If there is a serious risk that the responsible State does not respect its obligations of protection, the first State shouldn't transfer the applicant, otherwise it would breach its own human rights obligations.

The automaticity with which national authorities applied the above presumptions was challenged in the recent European case-law (both before the ECtHR and the ECJ) as will now be shown.

\footnotetext{
${ }^{25}$ This is also the reason why the Member States established a comprehensive set of standards applicable in all Member States in a non-discriminatory manner through the several secondary law provisions which are part of the Dublin system; Van der Klaauw, J. The EU Asylum Acquis: History and Context, in: Van Krieken, P.J. (Ed.). (2000). The Asylum Acquis Handbook, p. 14, T.M.C. Asser Press, The Hague, The Netherlands.

${ }^{26}$ See Preamble (2) of the Dublin Regulation; also Case C-411/10, NS v Secretary of State for the Home Department, [2011], not yet published, paragraph 79
} 


\section{Drawbacks of the Dublin System and the Assessment of the European}

\section{Court of Human Rights in the M.S.S. Judgment}

\subsection{Problems Occurring Within and Due to the Dublin System}

The Dublin Regulation never took into account the possibility that a Member State's asylum protection system could be affected by severe deficiencies. Indeed, this would have been contrary to the principle of respect of fundamentals rights on which the EU is based. ${ }^{27}$ However, the Dublin system has been criticised since the beginning in connexion with human rights. The Dublin Convention for instance had already at the time of the adoption been criticised on several grounds, among others the fact that it did not include in the determination of the responsible Member State an assessment of the capability of the Member State to receive a certain amount of asylum applicants and that it thus put a greater burden on certain Member states, in particular those having borders coinciding with EU external borders, such as Greece and Lithuania. ${ }^{28}$ This shortcoming hasn't been solved by the Dublin Regulation, which kept more or less the same criteria, even if in a different hierarchy. ${ }^{29}$ This has lead to several problems, in particular within the Greek asylum system. Indeed, according to FRONTEX, 90 percent overland asylum seekers enter the EU through Greece. ${ }^{30}$ In this case, if one of those asylum seekers applies for asylum in another Member State and no other

\footnotetext{
${ }^{27}$ See infra ; Bossuyt, M., 2010-2011. M.S.S. t/ Belgie en Griekenland, Rechtskundig Weekblad 40, p. 1711

${ }^{28}$ Such as Greece, Lithuania, etc. See Ferguson Sidorenko, O. (2007). The Common European Asylum SystemBackground, Current State of Affairs, Future. p. 47-48, also p. 56. T.M.C. Asser Press, The Hague, The Netherlands.

${ }^{29}$ See op. cit. Ferguson Sidorenko for an analysis of the criteria both under the Dublin Convention and the Dublin Regulation, in particular p. 57; In the year 2000, De Jong repeated this criticism de Jong, C. D. (2000). Harmonisation of Asylum and Immigration Policies, in The Asylum Acquis Handbook. Van Krieken, P.J. (Ed.), p. 32, T.M.C. Asser Press, The Hague, The Netherlands.

${ }^{30}$ Clayton, G. 2011. Asylum Seekers in Europe : M.S.S. v Belgium and Greece, Human Rights Law Review 11, p. 760
} 
higher criteria ${ }^{31}$ is applicable, Greece becomes the responsible Member State. Consequently, Member States are able to decline responsibility for asylum claims ${ }^{32}$ and the Greek asylum system is heavily overloaded. The direct consequences of this overload, coupled with a lack of means, are deficiencies in the protection of asylum applicants in Greece ${ }^{33}$

Furthermore, as there is no complete harmonisation of the asylum seekers' treatment in the various Member States, the treatment of an asylum application may be different, and in fact is different, throughout Europe. ${ }^{34}$ There are large disparities between the acceptance rates of asylum applications among the Member States. ${ }^{35}$ Therefore, the current system is far from granting the same chances to asylum applicants, depending on the Member State responsible for their application.

As Advocate General Trstenjak mentioned in her opinion, the system does not make any reference to the treatment of the asylum seeker in the responsible MS, neither in fixing the criteria for the determination of the responsible MS nor in connection with the mechanism of transfer. ${ }^{36}$

Already in 2008, the Commission proposed an amendment to the Dublin Regulation to make it more human. ${ }^{37}$ Jacques Barrot, the Commissioner in charge of Justice and Immigration explained to journalist Jean Quatremer" that "the Commission intend[ed] to set

\footnotetext{
${ }^{31}$ Those criteria are enshrined in Chapter III

${ }^{32}$ However, some scholars, as for instance Bossuyt, have criticised the relevance of this problem, by demonstrating that in practice, applicants are rarely transferred back to Greece.

33 HCR. (December 2009). Observations on Greece as a country of asylum, available under http://www.unhcr.org/refworld/pdfid/4b4b3fc82.pdf

${ }^{34}$ Report Pour un régime d'asile européen commun protecteur et pleinement respectueux de la Convention de Genève Recommandations de Forum réfugiés, available under http://www.forumrefugies.org/fr/Media/Files/Pour-un-Regime-d-Asile-Europeen-Commun-protecteur-etpleinement-respectueux-de-la-Convention-de-Geneve, p. 8

${ }^{35}$ Clayton, op. cit. p. 760

${ }^{36}$ Opinion of AG Trstenjak, paragraph 95

${ }^{37}$ Commission Proposal for a Regulation of the European Parliament and of the Council establishing the criteria and mechanisms for determining the Member State responsible for examining an application for international protection lodged in one of the Member States by a third-country national or a stateless person, COM(2008)820final, 3 December 2008

${ }^{38}$ Quatremer, J. (2011). Asile : la Cour de justice européenne dynamite le règlement « Dublin II », comment available under http://bruxelles.blogs.liberation.fr/coulisses/2011/12/asile-la-cour-de-justice-
} 
up a suspension mechanism of the Dublin system (...) which should be uncoupled whenever a Member State suffers from a great inflow of asylum applications". 39 This amendment had never been implemented, France, Germany and the UK opposing to it.

However, in the N.S. judgment, the ECJ is taking over this idea of suspending the transfer mechanism allowed by the Dublin Regulation in case of serious risks that the fundamental rights of the applicant will be breached. The Court thereby makes up for the lack of willingness of the Member States and finds a pragmatic solution to the problem.

\subsection{The Answer of the ECtHR : M.S.S. v. UK and the Requirement of Suspension of the Dublin Mechanism ${ }^{40}$}

This ECtHR judgment is particularly interesting because both the AG and the Grand Chamber took it into account to decide the N.S. case. The facts were quite similar to those of N.S. In M.S.S., an Afghan national entered through Greece, without applying for asylum there. He made a claim to that effect in Belgium. Pursuant to the Dublin Regulation, the Belgian authorities took an order to transfer him back to Greece. After having appealed the decision in Belgium, and asked the ECtHR to grant a provisional measure to suspend the transfer, which were both refused, he was finally transferred to Greece. He then complained to the ECtHR about his treatment in Greece, which he considered to be in breach of Article 3 and 13 of the ECHR, as well about the Belgian authorities' order to transfer him to Greece, which he considered as violating the same provisions.

The Court found in favour of the applicant by stating that both Greece and Belgium

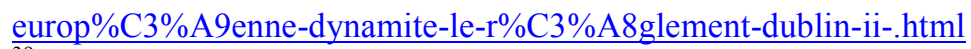

\footnotetext{
${ }^{39}$ Non official translation.

${ }^{40}$ For a more in depth analysis of this M.S.S. judgment see Moreno-Lax, V., op. cit.
} 
had breached Articles 3 and 13 of the ECHR.

For the purposes of the present discussion, it is sufficient to focus on the part of the judgment concerning the transfer of an applicant from one Member State (in this case Belgium) to another EU Member State (Greece), which was also the question at issue in the N.S. judgment. It must be pointed to the fact that the European Court of Human Rights only analyses the respect by Contracting States of the ECHR, and has no jurisdiction to assess the respect of the European Charter of fundamental rights as the ECJ does. ${ }^{41}$ However, we will see below that the ECJ took inspiration from this M.S.S. judgment when it ruled in the N.S. case and came to a similar conclusion.

It must also be noted that the ECtHR did not challenge the presumption according to which the EU system provides a protection of fundamental rights equivalent protection to that of the ECHR. ${ }^{42}$ Indeed, the "sovereignty clause" ${ }^{43}$ left sufficient discretion to the Member States for them to be held responsible under the ECHR and avoid the application of the presumption. $^{44}$ The Member State's implementation was thus challenged, not the EU

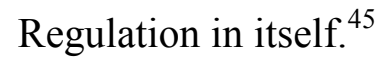

In essence, the Court had to decide if the Dublin mechanism respects the ECHR as well as the question if the two presumptions on which this transfer mechanism was founded are valid.

The ECtHR came to the conclusion that the respect of fundamental rights, as enshrined in the ECHR, prohibits Member States from blindly trusting other Member States under the

\footnotetext{
${ }^{41}$ Only the ECJ has jurisdiction to interpret the Charter of fundamental rights of the EU (Article 267 TFEU)

${ }^{42}$ Bosphorus v. Ireland, Application No. 4503/98, 30 June 2005

${ }^{43}$ Art. 3(2) Dublin Regulation

${ }^{44}$ M.S.S. v. UK, paragraphs 339 - 340

${ }^{45}$ See also on why the Bosphorus presumption is unlikely to apply to European Asylum law in general: Battjes, op. cit p. 75

However, the EU should accede to the ECHR soon (article 6 (2) TEU). From thereon, the ECtHR will be able to challenge EU law provisions directly.
} 
Dublin Regulation mechanism. ${ }^{46}$ It thus constitutes a brake to the mutual trust principle applied by the Member State under this Regulation. The transfer of an applicant to another Member State of the European Union is considered as being an expulsion measure and falls under the scope of the non-refoulement principle. This measure cannot be taken when there is a serious threat that the responsible Member State won't respect its obligations of protection under the ECHR. ${ }^{47}$

Already in the T.I. v. UK judgment ${ }^{48}$, the ECtHR refused the argument submitted by the UK which had claimed that it could remove an asylum seeker to Germany without breaching article 3 ECHR. The UK argued that it could rely on the Dublin Convention and that consequently Germany would examine the case, and not expel the applicant to his home country (Sri Lanka) where he would run the risk to suffer inhuman or degrading treatment. The ECtHR refused to accept the principle of compliance by all EU Member States with the ECHR. The ECtHR affirmed that the indirect removal to an intermediary country, which is also a Contracting State, does not affect the responsibility of the transferring Member State to ensure that the applicant is not, as a result of its decision to expel, exposed to treatment contrary to Article 3 of the Convention ${ }^{49}$. The Court continued by stating that absolve Contracting States from their responsibility under the Convention in the framework of an international organisation would be incompatible with the purpose and object of the Convention. So all the Member States involved in a "Dublin mechanism" leading to a breach of human rights are liable under the Convention.

However, the ECtHR had not found a Member State in breach of its obligations until now. The M.S.S. judgment therefore constitutes a fundamental change. If in a former

\footnotetext{
${ }^{46}$ As Labayle nicely expressed it : « le voile est déchiré ». Labayle, op. cit. p. 287

${ }^{47}$ Maiani, F., and Néraudau, E., op. cit. p. 5

${ }^{48}$ For a more in depth analysis of this judgment see Moreno-Lax, V., op. cit.

${ }^{49}$ T.I. v. UK, Application No. 43844/98, 7 March 2000. The Court expressed the refusal in the following words: "Where States establish international organisations, or mutatis mutandis international agreements, to pursue cooperation in certain fields of activities, there may be implications for the protection of fundamental rights".
} 
judgment, K.R.S v. UK ${ }^{50}$, the ECtHR still refused to condemn a State for a transfer of an applicant to Greece, this is not the case anymore in M.S.S. In K.R.S., Greece was presumed as fully complying with the Dublin system requirements and therefore, no risk of a violation of the applicant's human rights needed to be considered. With M.S.S., not only can a Member State no longer take it for granted that the receiving Member State will protect the fundamental rights of the applicants, but also it can no longer safely assume that the applicant will be safe from refoulement there. Mutual trust is not sufficient anymore to ensure an effective protection of the human rights. The Court specifies that the presumption of compliance cannot be absolute. On the one hand, the non-refoulement principle requires a concrete evaluation of the risks the person might be exposed to in the destination country. On the other hand, a breach by that Member State of its international obligations remains possible. In case of serious risks, the State must refuse to transfer the applicant. ${ }^{51}$ In order to condemn Belgium, the Court reasoned in three steps. First, Belgium knew of the situation in Greece. This constitutes the difference with K.R.S., where the knowledge was considered as not being sufficient. Belgium should therefore have verified that the asylum procedure in the responsible Member State offered sufficient guarantees to the asylum seeker. Secondly, Belgium could avoid the transfer because of the possibility to keep the case for itself left open by the sovereignty clause. Thirdly, and in conclusion, Belgium was under a duty to avoid the transfer.

Such a breach of Article 3 of the ECHR due to the knowledge by a Contracting party of the situation in the receiving country was also found in the Hirsi ${ }^{52}$ case. This case was slightly different. Several Somali and Eritrean nationals were part of a bigger group of migrants who left Libya in May 2009 aboard vessels trying to reach the Italian coast. The

\footnotetext{
${ }^{50}$ For a more in depth analysis of this judgment see Moreno-Lax, V. op. cit.

${ }^{51}$ Maiani, F. , and Néraudau, E., op. cit. p. 6

${ }^{52}$ Hirsi Jamaa and others v. Italy, Application no. 27765/09, 23 February 2012
} 
vessels were intercepted by the Italian authorities and the migrants brought back to Libya, despite their objections. Italy therefore relied on a bilateral agreement concluded with Libya on the fight against clandestine immigration which allowed the repatriation of migrants to Libya, so called "push-back operations". ${ }^{53}$ The ECtHR ruled that Italy could not blindly rely on the bilateral agreement and the presumption that Libya was a "safe country" on the assumption that it complies with its international commitments, including the principle of non-refoulement. On the contrary, as in M.S.S., Italy should have known of the situation in Libya $^{54}$, because this situation was "well-known and easy to verify" 55 and therefore it should have verified that the migrants wouldn't be exposed to the risk of inhuman or degrading treatment in Libya. Moreover, Italy should have ensured that Libya offered sufficient guarantees to prevent a removal of the person to his country of origin without an assessment of the risks faced there. ${ }^{56}$ Thereby, the Court attaches a lot of worth to the presumed knowledge of the circumstances in which the applicants find themselves in the receiving country, as it did in the M.S.S. ruling.

In the M.S.S. case, the Court thus clearly confirmed the primacy of the nonrefoulement principle over the effective application of the Dublin System. ${ }^{57}$ We will now turn to the decision of the ECJ in the N.S. case, which confirmed this primacy within the European legal order.

\footnotetext{
${ }^{53}$ This agreement has been suspended following the events of 2011.

${ }^{54}$ Because of the numerous reports of international organizations. See Hirsi v. Italy, paragraphs 128 and 131

${ }^{55}$ Hirsi v. Italy, paragraph 131

${ }^{56}$ Hirsi v. Italy, paragraph 147. The Court also precises that this "obligation is all the more important when, as in the instant case, the intermediate country is not a State party to the Convention".

${ }^{57}$ Maiani, F. , and Néraudau, E., op. cit. p. 5
} 


\section{The N.S. Decision}

The importance of this case is apparent from two external characteristics of the judgment. First, the case was allocated to the Grand Chamber. Second, no less than thirteen Member States, as well as the Swiss Confederation, the High Commissioner of the United Nations for the Refugees, Amnesty International and the AIRE Center intervened. This clearly shows that the matter at stake was one of great interest and topicality.

The first question asked in essence if the decision adopted by a Member State on the basis of Article 3(2) (i.e. the decision to examine the claim even if it is not the responsible Member State) fell within the scope of European Union law for the purposes of Article 6 TEU and/or Article 51 of the Charter. It was necessary to examine this issue because the Charter applies to Member States only where they are implementing EU law (Article 51 (1) Charter). Yet Mr N.S. could only rely on the rights given by the Charter if the United Kingdom was implementing EU law in its decision to transfer him to Greece. The Court ruled that the Charter indeed applies to the national decision to take responsibility for an asylum seeker even though the Dublin rules designate another Member State as responsible for the application $^{58}$. In either case, i.e. whether it decided to transfer the applicant to the responsible Member State, or to use the sovereignty clause, the United Kingdom was liable under the Charter.

The other questions referred to the Court related to whether the Member State which could transfer an applicant to the responsible Member State was obliged to assess the compliance of that Member State with EU law; if it could use a conclusive presumption that that State would observe those rights; if it could consider other Member States as "safe

\footnotetext{
${ }^{58}$ Paragraph 69 of the judgment
} 
countries"; and in the negative, if it was obliged to accept responsibility for the asylum application.

The Court first points to the fact that the CEAS was conceived in a context allowing the presumption that the participating Member States respect fundamental rights and that consequently the Member States could trust each other regarding this aspect ${ }^{59}$. This mutual trust was possible because of several reasons I've gone through before. However, mutual trust was only presumed, had shown its fragile points and had to be read carefully.

The Court concedes that the system could face problems, meaning that an asylum applicant could, in spite of all the requirements imposed by the EU asylum legislation and international treaties, be treated in a manner incompatible with its fundamental rights. ${ }^{60}$

Consequently, a conclusive presumption - such as the one found in UK law according to which all Member States are safe for asylum seekers breaches the Charter, because it would make the exercise of Charter rights inoperative. ${ }^{61}$ An applicant can thus rebut the presumption that the responsible state will respect his fundamental rights. In the NS case, the ECJ therefore took into account the M.S.S. judgment of the ECtHR to assess the situation in Greece ${ }^{62}$. This is also in line with the consistent case-law of the ECtHR that removal to an intermediate country does not affect the responsibility of a Contracting State to guarantee non-refoulement.

Nonetheless, it was important in order to preserve the effectiveness of the Dublin system to strike a fair balance between the integrity of the CEAS and the fundamental rights

\footnotetext{
${ }^{59}$ This mutual trust issue is also mentioned in paragraph 84 of the judgment reading as follows: "At issue here is the raison d'être of the European Union and the creation of an area of freedom, security and justice and, in particular, the Common European Asylum System, based on mutual confidence and a presumption of compliance, by other Member States, with European Union law and, in particular, fundamental rights."

${ }^{60}$ Paragraph 81 of the judgment

${ }^{61}$ Paragraphs 100-101 of the judgment. See also Peers, S. Court of Justice: The NS and ME Opinions - The Death of « Mutual Trust»?, available at http://www.statewatch.org/analyses/no-148-dublin-mutual-trust.pdf, p. 3

${ }^{62}$ Paragraphs $88-91$ of the judgment
} 
of asylum applicants. ${ }^{63}$ The Court thus specified that not every infringement of a fundamental right by the responsible Member State will have consequences on the application of the Dublin Regulation by other Member States. ${ }^{64}$ Indeed, this would deprive the obligations arising out of the Dublin system of their substance.

Only when there are such systemic flaws in the asylum procedure or reception conditions in the responsible Member State as are likely to result in inhuman and degrading treatment contrary to Article 4 of the Charter, will the transfer be in violation of the Charter. As a result, if the transfer is prohibited, the Member State where the application was made has to further analyse the criteria laid down in the Dublin Regulation to make further enquiries to determine the responsible Member State. Thereby, the Court does not follow the Opinion of Advocate General Trstenjak, who suggested that the Member State in which the application is lodged should automatically become responsible within the meaning of the Dublin regulation. ${ }^{65}$ However, in practice, even after a more thorough investigation, it will often be this same Member State which ends up responsible. ${ }^{66}$ Besides, the Court specifies that a Member State must examine the application itself if doing otherwise would worsen the situation of the applicant ${ }^{67}$ and jeopardise the aim of quickly determining the responsible Member State (which is one the main aims of the Dublin system). ${ }^{68}$ In those circumstances, the sovereignty clause included in the Dublin Regulation loses its "sovereign" character entirely. Instead of affording to Member States the possibility to keep the applicant if they so choose, it becomes the basis for a new obligation to which Member States never consented.

\footnotetext{
${ }^{63}$ Murphy, C. The ECJ on Aslyum, Greece \& the UK Protocol on the EU Charter (part1), comment available on http://www.humanrights.ie/index.php/2011/12/28/nsjudgment/

${ }^{64}$ Paragraphs $82-85$ of the judgment. The Court mentions that the contrary would not be compatible with the aims of the Dublin Regulation.

${ }_{65}$ Who suggested that the Member State automatically becomes responsible, Opinion of AG Trstenjak, paragraph 122 .

${ }^{66}$ Indeed, as has been said, most third country asylum seekers enter the EU through Greece. This circumstance, combined with Article 10 of the Dublin Regulation, leads to Greece being responsible.

${ }^{67}$ Paragraph 98 of the judgment

${ }^{68}$ See infra above.
} 
This new obligation might have far reaching consequences on the national asylum systems of Member States which until now transferred the applicants to Greece. ${ }^{69}$

\section{Consequences on the Dublin System}

This ruling is of major significance for the European Union. It shows that a judicial dialogue between the different Courts is of utmost importance, the ECJ having relied on the judicial notice given in the M.S.S. judgment. The Court referred explicitly to the M.S.S. judgment, as did the Advocate General. This is interesting because it shows the consequences of the changed introduced by the Lisbon Treaty in recognising the same value to the Charter as to the Treaties (TEU and TFEU), namely that of primary law. Article 52, paragraph 3 of the Charter implies that the ECJ cannot overrule the case-law of ECtHR. ${ }^{70}$ Indeed, in the N.S. ruling, the Court was very deferent to the finding of the Strasbourg Court in order to interpret the Charter. The judgment also clearly shows that the Charter has now become the primary source of human rights in the EU.

The question which arises after this ruling is "what is left of the Dublin system?". Long before the reported ruling, the Dublin system has been severely criticised ${ }^{71} \mathrm{~A}$ transfer carried out under the Dublin Regulation can indeed have real effects on the treatment of the asylum application. Sometimes, deficiencies in the national asylum system can even lead to a risk of violation of the fundamental rights of the applicant. As the M.S.S. judgment had

\footnotetext{
${ }^{69}$ Finally, the Court makes clear that the Protocol No 30 on the application of the Charter of Fundamental Rights to Poland and the United Kingdom does not have an incidence on the answers given.

${ }^{70}$ Maiani, F., and Néraudau, E., op. cit. p. 19. Article 52(3) of the Charter states that "in so far as this Charter contains rights which correspond to rights guaranteed by the Convention for the Protection of Human Rights and Fundamental Freedoms, the meaning and scope of those rights shall be the same as those laid down by the said Convention. This provision shall not prevent Union law providing more extensive protection".

${ }^{71}$ See infra part 4.1 .
} 
already shown, the efforts of the European Union to establish an asylum policy founded on solidarity, as required by Article 80 TFEU, were not sufficient and even had negative consequences on the protection of fundamental rights. ${ }^{72}$ Furthermore, the Regulation limits refugee's options considerably and at the same time it fails to ensure equal treatment of applications made in different Member States. ${ }^{73}$

According to some scholars, the problem of transfers of asylum applicants to Greece is minor because it can be demonstrated that in practice applicants are rarely transferred back to Greece. ${ }^{74}$ However, the human rights obligations at hand apply in an absolute manner. ${ }^{75}$ Moreover, to qualify as a violation of human rights it is not required that a certain threshold of persons be affected. Therefore, the argument that not a lot of applicants are transferred to Greece in practice does not lessen the breach of human rights caused by the transferring Member State.

With the NS judgment, some problems might now be solved: the suspension of the possibility to transfer an applicant to the responsible Member State when there are serious risks that his fundamental rights won't be protected in this State will reduce the risk of violation of human rights within the EU. It may also put pressure on the Member States to further negotiate amendments to the Dublin Regulation (in line with the Commission's proposal COM (2008)820 final $)^{76}$ and enhance the financial solidarity within the system. ${ }^{77}$ Some ideas have already been put forward. For instance, De Jong proposed to modify the Dublin system by creating a European board, which would decide on the asylum

\footnotetext{
${ }^{72}$ Maiani, F. , and Néraudau, E., op. cit. p. 16

${ }^{73}$ Murphy, C., op. cit.

${ }^{74}$ See for instance Bossuyt, M., 2010-2011. M.S.S. t/ Belgie en Griekenland, Rechtskundig Weekblad 40, p. 1707-1712

${ }^{75}$ Indeed, Article 3 and Article 13 of the ECHR do not contain any limitation clause.

${ }^{76}$ Moreno-Lax, op. cit. p. 28

${ }^{77}$ Financial solidarity is already the aim of the European Refugee Fund (ERF). This fund is mentioned in Ferguson Sidorenko, op. cit.p. 47
} 
applications. ${ }^{78}$ This would guarantee a fair and equal treatment of all asylum applications arising by third country nationals in the EU, and reach the other goals of the CEAS. Another possibility, less intrusive into Member States' sovereignty, would be to extend the competences of the European Asylum Support Office and entrust this agency with the responsibility to inform Member States authorities of any fact, study or court case relevant to the handling of asylum applications

However, some questions are left unanswered. One of these questions concerns the threshold necessary to have systemic deficiencies in a national asylum system. ${ }^{79}$ The question if there should be enquiry in every case as to whether the receiving State does not breach fundamental rights or only in cases concerning countries already targeted by human rights violations' reports such as those of the UNHCR will have to be answered by the national courts. Indeed, as the ECtHR recalled it in the Hirsi ruling, it is for the national authorities, faced with a situation in which human rights are systematically violated, to find out about the treatment to which the applicant would be exposed after its return. ${ }^{80}$ The ECJ surely clarified that not every breach is sufficient, but when are breaches sufficiently serious to warrant a refusal of transfer? For the sake of the effectiveness of the Dublin system, this question should be answered as soon as possible, either by the Member States themselves or by the ECJ. Otherwise, difficult questions will arise and asylum seekers could try to use the resulting uncertainty to appeal massively against all transfer decisions. In the worst case scenario, an asylum applicant would first have to bring the case before the ECtHR to obtain recognition that his human rights were breached. This however seems untenable with the future accession of the EU to the ECHR. From the moment of accession of the EU to the ECHR, it will indeed be the Union which will become responsible of the compliance of its legislation with the

\footnotetext{
${ }_{78}^{78}$ De Jong, p. 33, op. cit.

${ }^{79}$ As Moreno-Law showed, already concerning the sovereignty clause the national rules concerning levels and burdens of proof to set aside the transfer were quite different, op. cit. p. 17

${ }^{80}$ Hirsi v. Italy, op. cit. paragraph 133
} 
Charter. The ECtHR will thus analyse the compliance of the Dublin Regulation itself with the ECHR instead of assessing the implementation of the Regulation by the Member State as it did in the M.S.S. ruling.

Furthermore, systemic deficiencies will surely be very difficult to prove. Regarding this aspect, will only those reports on which the ECtHR and the ECJ already relied (such as the UNHRC report) be relevant or could national courts also rely on other documents, stemming from NGO's or national authorities? The specific form of the available evidence and the definition of the rules and principles governing the assessment of evidence are a matter for the national legal orders of the individual Member States. ${ }^{81}$ However, it would surely be easier if further regulation of asylum seeking procedures was carried out at EU level with the agreement of the Member States, instead of having only a vague obligation imposed by the Court and possible divergent interpretations by national courts. This obligation to verify the state of human rights protection in other Member State might indeed lead to divergences on the concept of systemic deficiencies itself, touching the core of Member States' sovereignty. In can be noted that the Member States already agreed on many aspects of asylum law, such as the reception conditions of applicants ${ }^{82}$, it thus seems possible that an agreement on the notion of systemic deficiencies can be reached.

Another question left open is whether the suspension solution arising out of the judgment could not also apply by analogy to other areas of Justice and Home Affairs law, like the European Arrest Warrant, as Steve Peers suggests? ${ }^{83}$ This would however not seem possible without a clear judgment of the Court in this field. Practitioners should nonetheless bear in mind that the Court might use a similar reasoning in case of human rights violations perpetrated in those matters.

\footnotetext{
${ }^{81}$ Opinion of AG Trstenjak,, paragraph 135

${ }^{82}$ Council Directive 2203/9/EC of 27 January 2003 laying down minimum standards for the reception of asylum seekers, OJ 2003 L 31, p. 18

${ }^{83}$ Peers, op. cit. p. 3
} 
Finally, will the accession of the European Union to the European Convention on Human Rights change anything? Even though, judging from the Bosphorus case, it can be expected that the ECtHR will show a considerable level of deference towards the EU, the possibility of scrutiny of EU actions by the ECtHR would certainly favour a rights-based approach. ${ }^{84}$ If a case such as the M.S.S. case would occur after the accession of the EU to the ECHR, the Bosphorus presumption would probably not be applied by the ECtHR, the Dublin Regulation and its sovereignty clause being at the very origin of the human rights violations. However, an analysis of this question would exceed the scope of the present article.

\section{Conclusion}

The ruling of the Court is not really surprising, as it follows the ECtHR's line of reasoning in M.S.S. However, the new obligation according to which Member States have to verify the actual respect of human rights in the receiving Member State imposes a high burden on the Member State which receives an asylum application. Those national authorities now have to find out about the actual treatment to which the applicant will be exposed if returned. Even if the ECJ does not render the sovereignty clause null and void, it nonetheless reduces quite much the room for manoeuvre left to the Member State in assessing whether they want to transfer an applicant or not. The Court thereby duly took into account the real conditions, i.e. the higher migratory pressure put on border Member States. As Moreno-Lax mentioned it

\footnotetext{
${ }^{84}$ Wiesbrock, A. (2009). Legal Migration to the European Union - Ten Years After Tampere. p. 134, Wolf Legal Publishers, Nijmegen, The Netherlands.
} 
concerning the M.S.S. ruling, mutual trust is not sufficient anymore. ${ }^{85}$ This has now officially been confirmed by the ECJ.

If the above analysis is correct, this burden is not however to be understood as a casespecific evidentiary burden. Member states are not obliged to enquire specifically about the likely situation of each asylum seekers if he or she were to be deported to another Member State. Rather, Member States are required not to turn a blind eye on available evidence of existing human rights violation, which seems a reasonable duty to impose on them. Given the severe deficiencies in the Greek asylum system, which could conceivably be lasting, it was important that the Court protect the human rights of asylum applicants not only in theory, but also in practice. The Court thereby also ensured the respect by the Union of its human rights obligations. Asylum applicants might now expect a fairer treatment of their application than beforehand. The analysis by national courts will have to take into account the real conditions of reception of the applicants within the receiving Member State, which in turn will avoid that the Member States breach their ECHR obligations by relying on the Dublin Regulation.

The N.S. ruling, such as the M.S.S. ruling, still does not dismantle the Dublin system. It nonetheless drastically redefines the sovereignty clause of the Dublin Regulation, turning it into an obligation in certain circumstances. This makes it even more urgent than after the M.S.S ruling to reform the system in order to give clear indications to the national authorities on the opportunities to transfer and to make the European system more coherent.

\footnotetext{
${ }^{85}$ Moreno-Lax, V., op. cit. p. 27
} 